\title{
ВИЗНАЧНИЙ НАУКОВЕЦЬ, ПЕДАГОГ І ЛІКАР Б.М. ДИКИЙ (ДО 80-РІЧНОГО ЮВІЛЕЮ)
}



Лиш праця світ таким, як є, створила, Лиш в праці варто і для праці жить.

І.Я. Франко

Стисло висвітлено основні біографрічні віхи й творчий доробок профресора Б.М. Дикого - відомого лікаря-інфекціоніста, педагога, науковця, профресора кафедри інфрекційних хвороб та епідеміології Івано-Франківського національного медичного університету.

Ці слова І.Я. Франка є життєвим девізом Богдана Миколайовича Дикого - доктора медичних наук, профресора кафедри інфекційних хвороб та епідеміології Івано-Франківського Національного медичного університету, заслуженого діяча науки і техніки України, якому 2 січня 2019 р. виповнилося 80 років.

Б.М. Дикий народився в 1939 р. у с. Лучинці Рогатинського району Івано-Франківської області. У 1957-1959 рр. навчався в Станіславському медичному училищі, з 1959 по 1962 р. служив в армії.

У 1968 р. Дикий Б.М. з відзнакою закінчив Станіславський медичний інститут (нині Івано-Франківський національний медичний університет).

Після закінчення інституту Богдан Миколайович навчався в аспірантурі на кафредрі мікробіології. Із 1971 р. працював асистентом цієї ж кафедри. У 1972 р. захистив кандидатську дисертацію, в якій довів хвороботворні властивості протею. Розробив метод лікування хворих із хронічними запальними процесами, ускладненими протейною інсрекцією з використанням карбеніциліну, продигіозану і лізоциму. Із 1978 р. зарахований на посаду асистента кафедри інфекційних хвороб, а з 1982 р. обраний на посаду доцента цієї кафедри.

У 1996 р. Богдан Миколайович вперше на Прикарпатті успішно захистив докторську дисертацію з інфекційних хвороб. Дисертаційна робота Дикого Б.М. пов'язана з вивченням клініко-імунологічного стану хворих на вірусні гепатити при фроновій ендокринопатії, особливостями перебігу інфекційних хвороб на фроні супутньої патології. Результати проведених досліджень розкрили нові сторони патогенезу гепатиту В на тлі тиреоїдної патології. Вчений довів, що тиреоїдні гормони суттєвим чином впливають на фрункціональний стан, реактивність і перебіг захворювань печінки. Вперше розроблені та запропоновані диференційно-діагностичні критерії гепатиту В із поєднаною патологією щитоподібної залози. Запропоновані ефективні схеми лікування таких хворих.

Докторська дисертація Богдана Миколайовича дала поштовх для визначення наукового напряму касредри: перебіг інфекційних хвороб на тлі супутньої патології. Під керівництвом Дикого Б.М. на кафедрі вперше застосований метод синглетно-кисневої терапії для лікування хворих на гіменолепідоз, мікст-інвазії, лептоспіроз на фоні цукрового діабету, спосіб лікування хворих з дисбактеріозом активованим біоспорином та біфрідобактерином, а також спосіб лікування хворих на хронічні гепатити різної етіології. Методика активації зазначених пробіотиків розроблена авторами кафедри. Ефективними науковими розробками вченого вперше обґрунтовано та доведено ефективність використання глутаргіну при лептоспірозі, вірусних гепатитах, протефлазиду при герпетичних інфекціях. Впродовж останніх років під керівництвом Богдана Миколайовича працівниками кафедри виконувались комплексні науководослідні роботи 3 державним фрінансуванням «Інфрекції TORCH-групи у ВIЛ-інфрікованих жінок репродуктивного віку» та «TORCH-інфекції у ВІЛ-інфрікованих осіб: особливості перебігу діагностики та лікування». За підсумками досліджень розроблені нові алгоритми діагностики цитомегаловірусної, токсоплазмозної, герпетичної інсрекцій у 
ВІЛ-інфрікованих осіб, впроваджено у практику нові способи лікування таких хворих з використанням замісної імуноглобулінотерапії та імунорегуляторних препаратів на основі рибонуклеїнової кислоти. Розроблені та впроваджені нові комплексні показники оцінки епідемії ВІЛ та роботи «Центру профрілактики ВІЛ-інсекції та боротьби зі СНІДом». Отримані ним результати лікування хворих опубліковані у наукових працях, використані у докторських і кандидатських дисертаціях. Під керівництвом Богдана Миколайовича захищено 3 докторські і 6 кандидатських дисертацій.

З 1991 по 2013 рр. завідував кафедрою інфекційних хвороб. У цей період на кафедрі відкрито магістратуру, аспірантуру та післядипломне навчання. За роки керування кафедрою «відвоював» у чиновників і відбудував навчальний корпус кафедри з лекційним залом та навчальними кімнатами, де створені всі умови для викладачів і студентів. За його сприяння й допомоги збудовані нові корпуси обласної клінічної інфекційної лікарні.

32014 р. в Івано-Франківському національному університеті створено спеціалізовану Вчену раду К 20.604.03 із захисту кандидатський дисертацій за спеціальностями «Інсекційні хвороби» та «Педіатрія», головою якої наказом МОН України призначено Дикого Богдана Миколайовича За період роботи спеціалізованої вченої ради вже 20 здобувачів з Києва, Львова, Чернівців та Івано-Франківська отримали звання кандидата медичних наук за цими спеціальностями.

Профресор Дикий Б.М. - автор і співавтор посібників «Внутрішні хвороби», «Епідеміологія» українською та англійською мовами, «Медико-профрілактичні аспекти ВІЛінфекції та СНІДу в лікарській практиці», «Практична інфектологія». В останні роки за співавторства Богдана Миколайовича видано підручники «Інфекційні хвороби»та «Епідеміологія», рекомендованих МОЗ та МОН України для студентів ВУЗів і лікарів для післядипломної освіти. Ним написано понад 400 наукових праць, 7 методичних рекомендацій, 18 рацпропозицій, 9 винаходів, захищених патентами України.

Богдан Миколайович бере активну участь у громадськовиховній роботі. Він $є$ головою обласного осередку гО «Всеукраїнська асоціація інсрекціоністів», членом редколегії медичних журналів «Клінічна інфектологія та паразитологія», «Інсрекційні хвороби», «Архів клінічної патології», «Профрілактична медицина», «Гепатологія», «Актуальна інфектологія».

Профресор Дикий Б.М. - спеціаліст вищої кваліфрікаційної категорії за фрахом «ннфекційні хвороби». Як клініцист він бере активну участь у консиліумах, патологоанатомічних конференціях, роботі наукового товариства іноекціоністів області. Під керівництвом Богдана Миколайовича підви- щують свій рівень знань лікарі-інфекціоністи області на передатестаційних циклах, тематичних удосконаленнях, стажуваннях.

У 2005 р. Богдану Миколайовичу Дикому присвоєно почесне звання заслуженого діяча науки і техніки України. Б.М. Дикий нагороджений почесною грамотою Міністерства охорони здоров'я України за багаторічну сумлінну працю, значний особистий внесок у розвиток вітчизняної науки та удосконалення педагогічного процесу, підготовку висококваліфікованих фрахівців охорони здоров'я, високий професіоналізм, відданість справі та активну громадську позицію, а також пам'ятною медаллю «Кращий науковець року» та дипломом «За значний особистий внесок у розвиток науки та освіти» обласною державною адміністрацією та обласною радою. У 2016 р. нагороджений відзнакою ГО «Всеукраїнська асоціація інфекціоністів» - пам'ятною медаллю Агапіта Печерського «За внесок у боротьбу з інфекційними захворюваннями».

Гасло: «Munguam petrorsum, semper ingrediendum» $(\mathrm{Hi}$ кроку назад, завжди вперед) залишається визначальним для Богдана Миколайовича Дикого у всіх справах. Отож: «Вперед!», - шановний ювіляре.

Завдяки високому професійному рівню, порядності й доброзичливості у стосунках, оптимізму Богдана Миколайовича люблять студенти, співробітники і друзі.

щиро вітаємо ювіляра і бажаємо міцного здоров'я, творчої енергії, щастя, добра та Божої опіки на довгі роки!

Президія Всеукраїнської асоціації інфекціоністів, колектив кафредри інфрекційних хвороб та епідеміології

Івано-Франківського національного медичного університету, Редакція журналу «/нфекційні хвороби».

\section{THE FAMOUS SCIENTIST, TEACHER AND DOCTOR B.M. DYKYI}

SUMMARY. Biographic and basic work of professor B.M. Dykyi are briefly reflected. He is an infectious diseases doctor, teacher, scientist, professor of Infectious Diseases Department of the Ivano-Frankivsk National Medical University.

Конфрлікту інтересів немає.

Authors have no conflict of interest to declare.

Отримано 8.01.2019 р. 